\title{
The treatment of the sea peril exception of the Hague-Visby Rules in common law and civil law jurisdictions
}

\author{
Marel Katsivela ${ }^{1}$
}

Received: 9 February 2015 / Accepted: 19 April 2016/Published online: 9 May 2016

(C) World Maritime University 2016

\begin{abstract}
The present study is a comparative analysis of the international ocean carrier of goods sea peril exoneration (article 4.2.c of the Hague and the Visby Rules) following Australian, English, Canadian, French, Italian, Greek and Chinese laws. The author analyses the main characteristics of the liability defence under the mentioned domestic laws in seeking to determine whether uniformity in the qualification of the exception exists or is possible.
\end{abstract}

Keywords Sea perils · Hague Rules · Visby Rules · Comparative analysis · Uniformity

\section{Introduction}

The history of sea perils dates back to ancient times. References to them - in the general sense of accidents of the seas - is found in the ancient Greek epic poem Odyssey of Homer ${ }^{1}$. Storms, thunder, sea monsters and sirens created some of the many obstacles delaying Ulysses from returning home to Ithaca. At that time, there seems to be no recorded law regulating the carrier's liability in the presence of such perils. It is the Rhodian law which later exempted the master from his contract to carry the goods if the vessel was unnavigable due to perils of the sea $^{2}$.

\footnotetext{
${ }^{1}$ Karl Witt, Homer, The Wanderings of Ulysses $3^{\text {rd }}$ ed (London: Longmans, Green, \& Co.) at 59. Odyssey dates back to 800 B.C. The Phoenicians and the ancient Egyptians were also skilled mariners braving the perils of the seas.

${ }^{2}$ Justinian Digest, 14, 2 (Rhodian Law), 10, 1 available at: http://www.mindserpent.com/American_History/books/ Justinian/digest/1904_monro_digest_of_justinian_vol_2.pdf. The Rhodian sea law dates back to $800-600$ B.C. At that time, Rhodes, the cradle of nautical jurisprudence, was sovereign of the seas. The Romans later conquered Rhodes and were inspired by the ancient Rhodian law in codifying sea laws although it is unclear to what extent they preserved it.
}

I would like to thank the common law section of the University of Ottawa for its financial support in completing this study. I would also like to thank my research assistants as well as the law professionals overseas for their comments.

Marel Katsivela

mkatsive@uottawa.ca

1 Programme de Common Law en Français, University of Ottawa Faculty of Law, Ottawa, Canada 
Similarly, today, article 4.2.c of the Hague and the Hague-Visby Rules ${ }^{3}$ exempts the international ocean carrier of goods from liability for 'perils, dangers and accidents of the sea or other navigable waters' ['sea peril(s)' or 'perils of the seas']. This provision constitutes one of the 17 liability defences that the carrier can invoke in case of cargo damage or loss. Sea perils are not further defined by the Hague and the Hague-Visby Rules. Domestic laws and/or case law are, therefore, called upon to determine the incidents that fall under this exception.

The question that naturally arises is how domestic laws and/or courts treat a sea peril: What are its conditions of application and its main characteristics? These questions are of interest to the present study ${ }^{4}$. The laws, case law and scholarly works of leading maritime nations will be considered: the UK (English law), Australia, Canada (common law jurisdictions) and France, Italy, Greece and China (civil law jurisdictions) ${ }^{5}$.

The Hague-Visby Rules apply today in Australia, the UK, Canada, France, Italy and Greece $^{6}$. In applying these rules, the three common law countries maintain the 17 carrier exoneration clauses in their domestic legislation. Interestingly, all the civil law

\footnotetext{
3 The International Convention for the Unification of Certain Rules of Law Relating to Bills of Lading, Aug. 25, 1924, 120 L.N.T.S. 155 (1924) (Hague Rules). The Hague-Visby Rules refer to the Hague Rules as amended by two protocols. The first protocol: 'Protocol to Amend the International Convention for the Unification of Certain Rules of Law Relating to Bills of Lading' (commonly known as the 'Visby Protocol 1968'), was adopted at Brussels on February 23, 1968 and entered into force on June 23, 1977. The second protocol: 'Protocol Amending the International Convention for the Unification of Certain Rules of Law Relating to Bills of Lading (August 25, 1924, as Amended by the Protocol of February 23, 1968)' (commonly known as the 'SDR Visby Protocol 1979'), was adopted at Brussels on December 21, 1979 and entered into force on February 14, 1984.

${ }^{4}$ Although the present study will not exhaustively examine all the different aspects of these questions, it will address important issues that fall under their scope. Subsidiary issues such as the vessel's seaworthiness, the carrier's and the claimant's burden of proof, other similar exemptions — such as the act of God one — causality, will not be commented on (in detail) in the present study.

${ }^{5}$ Even though Canada has a bijural tradition (common law and civil law), Canadian maritime law is largely inspired by common law principles, is uniform throughout the country and does not include provincial law: ITOInternational Terminal Operators Ltd v Miida Electronics Inc, [1986] 1 SCR 752. Chinese law will be very frequently referred to in the present study. However, it will not always be cited with the same frequency as the laws of other civil law countries. The author speaks and reads French, English, Greek and Italian and has personally consulted the cited texts in order to complete this article. Relevant parts of Chinese scholarly works, laws and case law appearing in the present study have been translated. The laws of some of these countries have been analysed in previous articles in greater detail. M. Katsivela, 'Perils of the Sea Peril under English, French and Greek Law; a Perilous Venture?' (2014) 20:5 The Journal of International Maritime Law 343-355, M. Katsivela, 'Qualifying the Hague and Visby Rules Sea Peril Exception Under English, Canadian, United States (US), French, Italian and Greek Law' (2015) 66 UNBLJ 301.

${ }^{6}$ For Australia, the UK, France, Italy and Greece see Comité Maritime International (CMI), 'CMI YearbookStatus of ratifications to Maritime Conventions' (2009) available at: CMI http://comitemaritime.org/Uploads/pdf/ CMI-SRMC.pdf. For Australia, see also the Australian Government, ComLaw, Carriage of Goods by Sea Act 1991 (2012) available at: http://www.comlaw.gov.au/Details/C2013C00662 which gives effect to the Hague-Visby Rules. The UK adopted the Hague-Visby Rules by the Carriage of Goods by Sea Act 1971, 1971 U.K. c. 19 also available at: http://www.legislation.gov.uk/ukpga/1971/19. Canada gives effect to the Hague-Visby Rules through domestic legislation: Part 5 of the Canadian Marine Liability Act (formerly known as the Carriage of Goods by Water Act), S.C. 2001, c. 6, also available at: http:/laws-lois.justice.gc.ca/eng/acts/M-0.7/page-11.html. In France, the following law and its amendments adopted the Hague-Visby Rules at the domestic level: Loi $n^{\circ} 66-420 \mathrm{du} 18$ Juin 1966 sur les Contrats d'Affrètement et de Transport Maritimes, available at: http://www.legifrance.gouv.fr/ affichTexte.do;jsessionid=4376BC8E267D2BAA67EDE3703F01A3AA.tpdjo10v_2?cidTexte= JORFTEXT000000692464\&dateTexte=20101103. Greece ratified the Hague-Visby Rules in 1992 with the adoption of law 2107/1992, N. 2107/1992 (ФEK A 203), also available at: NOMOS http:/lawdb.intrasoftnet.com/nomos/nomos_ frame.html. The Hague-Visby Rules were incorporated into Italian law by L. 12 June 1984, n. 243, 244.

Despite the application of the Hague-Visby Rules in the mentioned countries, the present study will also focus on Hague Rules case law (more frequently bill of lading cases rather than insurance ones) since the sea peril exemption remained unchanged in the two sets of rules.
} 
countries referred to in the present study have adopted maritime or transport codes commonly cited by case law when commenting on the ocean carrier sea peril exception ${ }^{7}$. These codes often consolidate various carrier excepted perils-including the present one - into more encompassing legal categories. In this way, article L5422-12 (3) of the French Code des Transports groups several Hague-Visby Rules liability exceptionsacts of war, acts of God, sea perils, acts of public enemies, the arrest or restraint of princes [...] and quarantines - under the following exoneration clause: '[...] event [s] non attributable to the carrier' ([...] événement [s] non imputable au transporteur) ${ }^{8}$. Article 422 of the Italian Code of Navigation treats acts of God and sea perils as one

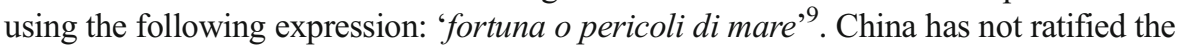
Hague, Hague-Visby or the Hamburg Rules but has adopted the Maritime Code of the People's Republic of China (MCPRC) which has borrowed from these rules ${ }^{10}$. In its article 51, the code maintains most of the Hague and the Hague-Visby Rules' liability

\footnotetext{
${ }^{7}$ France: Code des Transports, JO, 3 November 2010, available at: https://www.legifrance.gouv.fr/ affichCode.do?cidTexte=LEGITEXT000023086525\&dateTexte=20101202 Italy: Codice della navigazione (Code of Navigation) available at: http:/www.fog.it/legislaz/cn-0376-0468.htm. Greece: Code of Private

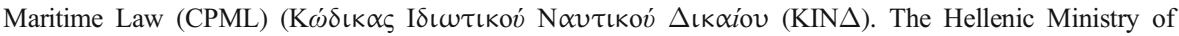

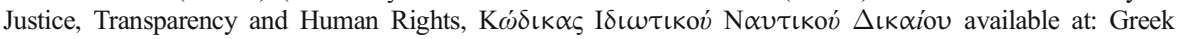
Ministry of Justice http://www.ministryofjustice.gr/site/kodikes/. For China's Maritime Code of the People's Republic of China (MCPRC) see infra note 10.

It should be noted that the civil law and the common law traditions do not attribute the same importance to the different sources of law. In civil law, legislation, codes and, generally, written laws are the primary source of law-with case law being an increasingly important interpretive source. Civil law judges do not habitually create law but interpret written laws declaring the intent of the legislator. As Montesquieu notes, 'domestic judges are no more than the mouth that pronounces the words of the law' («Mais les juges de la nation ne sont [...] que la bouche qui prononce les paroles de la loi»): Charles de Secondat, Montesquieu, L'Esprit des Lois vol.1 (Livre XI, ch. VI, 1768) at 327. On the contrary, the role of judges in common law is not limited to declaring the rules contained in written laws. It also involves creating law on a case by case basis through the formulation of precedents. Stephen Waddams, The Study of the Law 7th ed (Toronto: Carswell, 2010) at $17,79 \mathrm{~s}$. These precedents are binding upon the parties involved in the specific dispute and are also binding upon the judges in deciding future cases based on similar facts. Scholarly works (for example, expert scholarly opinion, treatises and case commentary) carry less weight in common law than in civil law systems. For the importance of doctrine in civil law, see Kelly Buchanan, 'The Role of the 'Doctrine' as a Source of Law in France' (20 December 2010), online: Library of Congress <http://blogs.loc.gov/law/2010/12/the-roleof-the-doctrine-as-a-source-of-law-in-france/>. For common law, see Donald Poirier, Anne Françoise Debruche, Introduction Générale à la Common Law, 3th ed (Cowansville, Canada: Yvon Blais Inc., 2005) at 130-132. It should be noted that while common law countries refer to 'scholarly works' to describe the work of expert scholarly opinions and commentary, civil law countries refer to 'doctrine' to identify the same.

${ }^{8}$ Ibid (France-Code des Transports).

${ }^{9}$ Supra note 7 for the Italian code. Giorgio Righetti, Trattato di Diritto Marittimo, Tome II (Italy: Giuffrè Editore, 1990) at 741 s. [Righetti], Leopoldo Tullio, Massimo Deiana, Codice dei Trasporti (Italy: Giuffrè Editore, 2011)[Tullio] at 675.

${ }^{10}$ Standing Committee of the National People's Congress, 'Maritime Law of the People's Republic of China' (1992) http://www.lawinfochina.com/display.aspx?lib=law\&id=191 (version in English and in Chinese). For the English version of the code, see also Ministry of Commerce, People's Republic of China, Maritime Code of the People's Republic of China (1992) available at: http:/english.mofcom.gov.cn/aarticle/lawsdata/ chineselaw/200211/20021100050726.html. The MCPRC entered in force in 1993. Chapter IV of the code applies to the international ocean carriage of goods. For more details on the code, see Xia Chen, 'Chinese Law on Carriage of Goods by Sea under Bills of Lading' (1999) 8-WTR Currents: Int'l. Trade L.J. 89 at 90 [Chen]. See also Zhang Lixing, 'Recent Maritime Legislation and Practice in the People's Republic of China' (19931994) 6 U.S.F. Mar. L.J. 273 at 281.
} 
exceptions ${ }^{11}$ and specifically provides, in article 51.1.3, that the carrier shall be exempted from liability in case of 'force majeure and perils, dangers and accidents of the sea or other navigable waters' ${ }^{12}$. In reality, the Chinese text of the code uses, instead of force majeure, the term 天灾 (tian zai) which means 'act of God'13. Although the lack of clarity in the language used is obvious - the terms 'force majeure' and 'sea perils' appear in the English version of the code while reference to 'act of God' instead of 'force majeure' is made in the code written in Chinese - the Chinese provision suggests that the sea peril and the act of God liability exceptions appear under one exoneration clause in the MCPRC. It is only in Greece that the CPML has not created a combined exception and exonerates the ocean carrier of goods for 'events emanating from the sea' ( $\varepsilon \mathrm{K}$

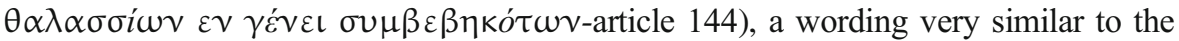
one present under the Hague and Hague-Visby Rules article 4.2 (c) $)^{14}$.

The divergent domestic law provisions suggest that similarities as well as differences may exist in the treatment of the sea peril exception in the mentioned jurisdictions. The present study aims at describing, in greater detail, the applicable principles and determines the extent to which uniformity exists or is possible. If uniformity exists, the intent of the drafters of the Hague-Visby Rules would be honoured ${ }^{15}$. In the absence of uniformity, ways will be sought to approximate the divergent domestic laws.

The complexity of the comparative analysis is not negligible. It will be commenting on laws and case law of different jurisdictions regarding the Hague-Visby Rules sea peril ocean carrier exoneration clause. The common law and civil law traditions as well as the extreme variety of languages spoken in the countries under examination add to the richness but also to the complexity of the analysis. The study will also seek to determine the extent to which uniformity of domestic laws and case law is present or possible. These considerations involve a cross-country comparative legal study and research of various legal issues which constitutes quite a challenging task.

The article is divided into two sections: Section I describes the sea peril defence in the mentioned common law and civil law jurisdictions. Section II compares and analyses the applicable principles.

\footnotetext{
${ }^{11}$ Some of the Hague and Hague-Visby Rules exceptions (for example, act of public enemies) are left out because they do not have much practical significance today. Other exceptions (insufficiency of packaging and marking) have been merged. John Shijian Mo, Shipping Law in China (Hong Kong: Sweet \& Maxwell, 1999) at 100 [John Mo].

${ }^{12}$ Following the English translation of the code, supra note 10.

${ }^{13}$ For the Chinese text of the Maritime Code, see ibid. For the translation of 天灾 as 'act of God' see Act of God, Dict.cn available at: http://dict.cn/act\%20of\%20god and interview of the author with Yao Hongxiu, Professor of Maritime Law, Law school, SMU (Shanghai Maritime University) in China. Some authors refer to the mentioned Chinese term as 'natural disaster' and not as force majeure. John Mo, supra note 11 at 100. It is said that the use of the force majeure term to translate 天灾 is wrong. Interview of the author with Yao Hongxiu, Professor of Maritime Law, Law school, SMU (Shanghai Maritime University) in China.

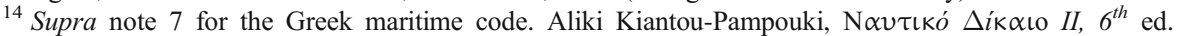
(Thessaloniki, Greece: Sakkoula editions, 2007) at 536 [Pampouki]. The Greek maritime code has consolidated other Hague and Hague-Visby Rules exoneration clauses.

${ }^{15}$ In effect, in devising these rules, the idea of its drafters was to adopt uniform regulations regarding the carrier's obligations and his exemptions from liability. Comité Maritime International, The Travaux Préparatoires of the Hague and of the Hague Visby Rules available at: Comité Maritime International http://www.comitemaritime.org/Uploads/Publications/Travaux\%20Preparatoires\%20of\%20the\%20Hague\% 20Rules\%20and\%20of\%20the\%20Hague-Visby\%20Rules.pdf at 27 [travaux].
} 


\section{The sea peril exception: common law and civil law views}

Following English, Australian and Canadian law, sea perils are a carrier defence that includes events peculiar to the sea or to a ship at sea such as an accidental incursion of seawater, currents, storms, collisions, tides and stranding ${ }^{16}$. What constitutes such an event in all jurisdictions is examined on a case-by-case basis considering all the relevant circumstances: the nature of the event, its duration, the location and the time of the year during which it takes place, the condition/intensity of the wind, the sea and the waves, the duration of the voyage, the damage to the vessel and the goods, the type of transported goods, etc. ${ }^{17}$.

Under Australian law, the leading case Bunga Seroja and Shipping Corp of India Ltd $v$ Gamlen Chemical Co (A/Asia) Pty Ltd, $[\text { Gamlen }]^{18}$ focus on this excepted peril. In Gamlen, drums of cleaning solvent stowed in the ship's hold broke free and sustained extensive damage due to bad weather experienced when crossing the Great Australian Bight. The weather conditions were unusual but not unforeseeable. From the facts of the case, it was clear that improper stowage was a cause of the loss and a breach of the carrier's article III.2 obligation to properly and carefully stow the goods carried ${ }^{19}$. The appellant carrier contended that the damage was caused by the weather. The High Court rejected this submission. It deemed that the carrier's failure to carefully and properly stow the respondent's goods was the decisive cause of the damage and had to be read jointly with the sea peril exception: 'It seems to us that an accurate reflection of these findings requires one to treat the two concurrent causes of the loss as inseparable and therefore joint ${ }^{20}$. Consequently, the carrier could not be exonerated ${ }^{21}$. Regarding the foreseeability of the supervening occurrence, the court noted that it does not constitute a condition of application of the defence: '[...] sea and weather conditions which may reasonably be foreseen and guarded against may constitute a peril of the sea ${ }^{22}$.

\footnotetext{
${ }^{16}$ English law: The Xantho (1887), 12 App. Cases 503 (HL) [The Xantho], Hamilton, Fraser \& Co. v Pandorf \& Co (1887), 12 App. Cas. 518 (HL)[Pandorf]. Canada Rice Mills $v$ Union Marine, 67 Ll. L.R. 549 (PC) [Rice Mills], an insurance case. Stewart C. Boyd, Steven Berry, Andrew S. Burrows, Bernard Eder, David Foxton, Christopher F. Smith, Scrutton on Charterparties and Bills of Lading 21st ed (London, U.K.: Sweet \& Maxwell, 2008) at 206-209 [Scrutton]. A significant proportion of cargo damage is due to sea perils in the broad sense of incursion of seawater or the action of the weather. Sir Richard Aikens, Richard Lord, Michael Bools, Bills of Lading (London, U.K.: Informa Maritime \& Transport, 2006) at 274 [Aikens]. Australia: Great China Metal Industries Co Ltd v Malaysian International Shipping Corp Berhad, (1998) [1999] 1 LL. Rep. $512(\mathrm{HC})$ at para 77 [Bunga Seroja] referring also to English law. Canada: Canadian National Steamships v Bayliss, [1937] SCR 261 at 263 [Bayliss], Keystone Transports Ltd. v Dominion Steel \& Coal Corp., [1942] SCR 495, 1942 CarswellQue 36 at para 26 [Keystone] referring to English case law and/or doctrine.

${ }^{17}$ For some of these elements under English law, see ibid. Australia: Bunga Seroja, ibid at para 147. Canada: Keystone, ibid, Bruck Mills Ltd. v Black Sea Steamship Co., [1973] FC 387 (FCC), 1973 CarswellNat 32, [Bruck Mills], The Washington, (1976) 2 Lloyds Rep. 453 (FCC) [The Washington].

${ }^{18}$ Bunga Seroja, ibid, Gamlen, 147 CLR 142 (HC). Both Australian holdings are deemed to be 'good law', 'settled law' in Australia considering that Bunga Seroja generally follows Gamlen. Michael White, Australian Maritime Law 3rd ed. (Australia: The Federation Press, 2014) at 203-204. As it was stated in Bunga Seroja, there is no 'single all-embracing definition' of a sea peril capable of unvarying application to all circumstances. Bunga Seroja at para 41.

${ }^{19}$ Gamlen, ibid at 163 . Article III.2 provides: '2. Subject to the provisions of Article IV, the carrier shall properly and carefully load, handle, stow, carry, keep, care for and discharge the goods carried'.

${ }^{20}$ Gamlen, ibid at $163-164$.

${ }^{21}$ Ibid.

${ }^{22}$ Gamlen, ibid at 166.
} 
The Gamlen holding regarding the foreseeability of a sea peril was followed by the more recent leading case Bunga Seroja ${ }^{23}$. Here, coils of aluminium were shipped from Sydney to Keelung, Taiwan. Cargo damage was caused by a storm (winds of force 10 11 and wave heights of 10-11.5 m) encountered in the Great Australian Bight. The adverse weather was not only foreseeable but, actually, foreseen. Its intensity, however, was beyond the gale conditions stated in the forecast. The cargo owner sued the respondent carrier alleging a breach of the carrier's article III obligations ${ }^{24}$. The court found that there was no such breach. It concluded that the carrier had provided a seaworthy vessel and had carefully and properly stowed the transported goods. Consequently, the perils of the sea liability exception did not have to be examined ${ }^{25}$. On the foreseeability of the sea peril exception, the court agreed, obiter, with Gamlen contrasting the Anglo-Australian approach to the US-Canadian one ${ }^{26}$ :

[...] But if it is necessary to consider the 'perils of the sea' exception the fact that the conditions that were encountered could reasonably be expected or were forecast could not be taken to conclude that question. To that extent we agree with what was said by Mason and Wilson JJ in Gamlen. Such an approach, even if it is different from the American and Canadian approach, better reflects the history of the rules, their international origins and is the better construction of the rules as a whole. [...] Under the Anglo-Australian approach, the critical question is not whether the peril can be foreseen or guarded against but whether the harm causing event was of the sea and fortuitous, accidental or unexpected.

It was further noted that 'in the UK and Australia, it is not necessary that the losses or the cause of the losses should be 'extraordinary'. Consequently, sea and weather conditions which may reasonably be foreseen and guarded against may constitute a peril of the sea' 27 .

In effect, leading English cases such as The Xantho ${ }^{28}$ have applied the sea peril exception in the presence of non-extraordinary perils: A storm whose force is not

\footnotetext{
${ }^{23}$ Bunga Seroja, supra note 16. In the present article, the force of the winds is based on the Beaufort scale. ${ }^{24}$ For article III.2, see supra note 19. Article III.1 provides:

1. The carrier shall be bound before and at the beginning of the voyage, to exercise due diligence to- (a) make the ship seaworthy; (b) properly man, equip and supply the ship; and (c) make the holds, refrigerating and cool chambers, and all other parts of the ship in which goods are carried, fit and safe for their reception, carriage and preservation.

${ }^{25}$ Bunga Seroja, supra note 16 at para 97 . This holding subjects the availability of the sea peril defence to a breach of carrier's article III obligations. In so doing, the court departs from the burden of proof enunciated in Gamlen and the English case The Glendarroch that require the carrier to establish the cause of the damage or loss (sea peril or other defence) before the burden of proof shifts to the cargo claimant to prove the carrier's negligence. Bunga Seroja at para 22. See also Martin Davies, 'International Maritime Law Application of the Hague Rules 'Perils of the Sea' Defense in Australia: The Bunga Seroja (1999) 23 Tul. Mar. L.J. 449 at 460 , 461 and Michael White, Craig Forrest, (2008) 'Australian Maritime Law Update: 2007 General Maritime Issues’ 39(3) J. Mar. L\&Com. 333 at 346. As stated, burden of proof issues will not be analyzed in detail in the present study.

${ }^{26}$ Bunga Seroja, supra note 16 at paras 51, 101, see also paras 58, $102,147$.

27 Bunga Seroja, ibid at para 39, Gamlen, supra note 18 at 166. It should also be noted that under English law, if the vessel's unseaworthiness at the beginning of the voyage is the (concurrent) cause of the cargo damage or loss, the sea peril exception cannot be invoked by the carrier. Providing a seaworthy vessel is an overriding obligation under English law: excepted perils cannot be invoked by the carrier if the vessel's seaworthiness is not first established. Maxine Footwear Company Ltd. v. Canadian Government Merchant Marine Ltd., (1959) 2 L1. Rep.105. The Torenia, (1983) 2 L1. L. Rep. 210 (QB).

${ }^{28}$ The Xantho, supra note 16, Rice Mills supra note 16, The Stranna, [1937] 2 All ER 383 (Admlty) (affirmed on appeal): [1938] 1 All ER 458 (CA). Scrutton supra note 16 at 208.
} 
exceptional or a ship running on a sunken rock in calm weather may fall under this exception. In Pandorf, a cargo of rice was damaged while travelling between Burma and Germany. It was discovered that rats had gnawed a hole in a pipe of the vessel, leading to the escape of seawater and subsequent damage to the cargo. In treating this rather non-extraordinary incident as a sea peril in the absence of negligence, Lord Macnaghten stated ${ }^{29}$ :

Under these circumstances it seems to me that the accident which caused the damage was one of the excepted perils or accidents and that there is no reason why the shipowner should not avail himself of the exception. It was an accidental and unforeseen incursion of the sea that could not have been guarded against by the exercise of reasonable care.

In agreeing with the majority opinion, Judge Fitzgerald added that the fact that the accident was fortuitous, unforeseen and unknown does not mean that 'to constitute a peril of the sea the accident or calamity should have been of an unforeseen character ${ }^{30}$. Carver and other authors agree with this position ${ }^{31}$.

However, there are English cases where the foreseeability of the supervening event has disallowed the application of the sea peril exception. For example, in The Tilia Gorthon $^{32}$, a cargo of timber was lost overboard due to adverse weather conditions (rough seas and winds of force 10 in the Atlantic Ocean) encountered in transit. In holding the carrier liable, the court stated that the possibility of encountering adverse weather conditions could not be ignored ${ }^{33}$.

[...] the evidence as to the weather has not satisfied me that the conditions encountered were such as could not and should not have been contemplated by the shipowners [...] winds of [...] force 10 [...] are by no means so exceptional in the North Atlantic in the autumn and winter that the possibility of encountering them can be ignored.

This and other similar holdings were referred to by the Australian Bunga Seroja ${ }^{34}$. The court opined, however, that the Hague and the Visby Rules were designed to exonerate carriers in the absence of negligence rather than due to unforeseeable perils $\mathrm{s}^{35}$.

Citing English authority cases, Canadian decisions do not regard sea perils as extraordinary events. It has, therefore, been held that winds described in the ship's logbook as 'fresh' and 'strong ${ }^{36}$ or the sinking of two barges in calm weather ${ }^{37}$ may fall under this defence. However, sea perils in Canada need to be unforeseeable

\footnotetext{
${ }^{29}$ Pandorf, supra note 16 at 530. In other cases, however, the defence did not succeed due to the carrier's or his agent's negligence. In The Oquendo (1877), 38 LT 151, the defence was rejected since the damage to the cargo by salt water was due to improper stowage.

${ }^{30}$ Pandorf, supra note 16 at 528.

${ }^{31}$ Infra note 75 and accompanying text.

32 The Tilia Gorthon (1985), 1 Ll. Rep. 552 (QB) [The Tilia Gorthon].

${ }^{33} \mathrm{Ibid}$ at 555. See also Aikens, supra note 16 at 274-275.

${ }^{34}$ Bunga Seroja, supra note 16 at para 189-193.

${ }^{35}$ Bunga Seroja, supra note 16 at para 225-226. The Tilia Gorthon was deemed by Bunga Seroja as no more than a decision about particular facts (para 46).

${ }^{36}$ Keystone, supra note 16 at para 34-35. William Tetley, Marine Cargo Claims, 4 th ed., (Cowansville: Yvon Blais, 2008) at 1065.

${ }^{37}$ Consolidated Mining \& Smelting Co. v Straits Towing Ltd., [1972] FC 804 (FCC), 1972 CarswellNat 41 [Consolidated Mining] at para 84-85. See also Goodfellow, infra note 38 at 526 referring to English law. In this respect, the Australian Bunga Seroja and Gamlen holdings stating that under US/Canadian law sea perils need to be extraordinary in nature are not justified for Canada.
} 
occurrences. In the leading case Charles Goodfellow Lumber Sales Ltd. v Verreault $[\text { Goodfellow }]^{38}$, the cargo owner instituted an action for the loss of the greater part of a shipment of creosoted timber that occurred when the respondent's vessel encountered a gross swell and winds at sea. The carrier invoked the sea peril exception in order to escape liability. The court found that the carrier was liable since the vessel was unseaworthy and added the following on the sea peril exception ${ }^{39}$ :

In order to constitute a peril of the sea there must be something which could not have been foreseen or guarded against as one of the probable incidents of the voyage. The weather encountered was such as should have been foreseen as one of the probable incidents of a voyage in the waters in question.

Further, negligence on the part of the carrier or his agents disallows the operation of the defence. In Keystone ${ }^{40}$, a cargo of nails, staples and wire was shipped from Sydney, Australia to Ontario, Canada. In transit, the vessel encountered strong winds- described as 'fresh wind' and 'strong wind' in the log book - and waves covering the bridge of the vessel. This resulted in an infiltration of seawater into the vessel damaging the cargo due to the loosening of the tarpaulins covering the hatches. In the action that followed, the carrier invoked the sea peril defence. The court held that sea perils do not need to be extraordinary in nature in order to exonerate the carrier and that the negligence of the carrier or his agents was not established ${ }^{41}$. Judge Taschereau specifically noted $^{42}$ :

From these authorities it is clear that to constitute a peril of the sea the accident need not be of an extraordinary nature or arise from irresistible force. It is sufficient that it be the cause of damage to goods at sea by the violent action of the wind and waves, when such damage cannot be attributed to someone's negligence.[...] Under these circumstances, no negligence can be imputed to the officers and crew who were watchful and alert [...] They were not bound to take all the precautions that would inevitably prevent the accident and make its occurrence impossible. They were required to exercise the care that reasonably prudent men would exercise in similar circumstances. It has been argued that the crew did not discover immediately the damaged condition of the tarpaulins. The failure to make such an immediate discovery does not amount to negligence under prevailing conditions of the weather...

\footnotetext{
38 [1971] SCR 522. Cited by the more recent case Kruger Inc. v Baltic Shipping Co., [1988] 1 FC 262, 1987 CarswellNat 200 upheld on appeal by Kruger Inc. v Baltic Shipping Co., [1989] FCJ No. 229, 2006 CarswellBC 2566 (FCA). See also Consolidated Mining, ibid, and Tetley, supra note 36 at 1065-1066, $1040-1042$.

${ }^{39}$ Ibid at 522-523.

${ }^{40}$ Keystone, supra note 16

${ }^{41}$ Ibid at para 33, 37, 38. In other cases, however, the defence did not succeed. In Falconbridge Nickel Mines Ltd. v Chimo Shipping Ltd., [1969] 2 Ex. C.R. 261 (Ex. C.C.), 1969 CarswellNat 362 at para 76 affirmed by Falconbridge Nickel Mines Ltd. v Chimo Shipping Ltd., [1974] SCR 933, 1973 CarswellNat 363 [Falconbridge], the defence failed due to the fact that 'the danger of damage to the cargo arising from the weather conditions could and should have been guarded against, by adequately securing it to keep it from sliding, and by tethering the barge to the ship'. On the carrier's absence of negligence in guarding against the event, see also Kruger (supra note 38 at para 41-42) and Tetley, supra note 36 at 1065-1066, 1040-1042. 42 Ibid.

It may be suggested that this holding approximates the Bunga Seroja since it does not insist on the sea peril's unforeseeability. In the abovementioned Goodfellow Supreme Court case, however, the court specifically stated that Keystone should not be interpreted in this way: There 'must be something which could not be foreseen as one of the necessary incidents of the adventure'. Supra note 38 at 530-531 quoting case law.
} 
In the civil law jurisdictions under examination, sea perils are viewed as events attributed to the sea and to the specific conditions of sea navigation such as an incursion of seawater into the vessel, rough seas, storms, large waves, stranding on shoals or coastal rocks, etc. ${ }^{43}$. Civil law cases often refer to sea perils as exceptional events or events involving extreme weather conditions - winds of force 10-12 and waves of 6$8 \mathrm{~m}$ or an exceptional wave, similar to what mariners call a freak wave ${ }^{44}$. However, French, Italian and Greek law suggest that incidents of no exceptional nature (i.e. a swell of no exceptional force) may constitute sea perils ${ }^{45}$. Various factors are considered in determining the presence of a sea peril: the force of the wind, the state of the sea, their duration, the season and location in which they take place, their effect on the vessel, the size of the vessel, etc. ${ }^{46}$.

Under the domestic maritime codes of almost all the civil law countries under examination (France, Italy and China), the act of God and the sea peril Hague-Visby Rules exceptions - and sometimes others as well-are combined into one exoneration clause $^{47}$. In these countries, the combined liability exceptions have traditionally constituted unforeseeable and irresistible events, characteristics that approximate them

\footnotetext{
${ }^{43}$ France: CA Paris, 2 February 1971, (1971) DMF 222 at 227, 230 (note René Rodière)[The Armorique], Pierre Bonassies, Christian Scapel, Droit Maritime 2nd ed (Paris: L.G.D.J., 2010) at 734 [Scapel]. Italy: Righetti, supra note 9 at 744. Case law in Italy does not seem to insist on this characteristic of sea perils. Greece: Pampouki, supra note 14 at 178 also referring to foreign doctrine. See also CA Piraeus, 121/2003 (377944), CA Piraeus, 259/1990 (3375). Unless otherwise stated, all Greek cases referred to herein can be found online using the Greek law database NOMOS, available at: http:/lawdb.intrasoftnet.com/nomos/ nomos_frame.html. China: Smart Freight Transport \& Logistics Ltd v Yang Ming Marine Transport Corp et al. (24 July 2008), Shanghai Maritime Court Commercial Trial Decision 221, available at: Shanghai International Platform for Maritime Legal Information http://shhsfy.gov.cn/hsinfoplat/platformData/infoplat/ pub/hsfyintel_32/docs/200907/d_199672.html[Smart Freight]. In China, there are ten maritime courts. Since the decisions of each maritime court are not binding on other courts (only the decisions of the Supreme People's Court are binding), it is not uncommon for maritime courts to have different views when considering similar cases.

${ }^{44}$ France: Trib Com Paris, 14 March 1973, (1974) DMF 161 at 161, 163, Cass Com, 1 December 2009, (2010) DMF 19 at 27, Scapel, supra note 43 at 735. Italy: CA Trieste, 3 December 1982, (1983) Dir. Mar. 540 at 543-544 [Trieste 1982], Cass, 4 April 1957, (1958) Dir. Mar. 67 at 70, Francesco Berlingieri, International Maritime Conventions vol.1 (UK: Routledge, 2014) at 30, 31 [Berlingieri, 2014] also referring to case law. Greece: CA Piraeus, 801/1992 (64113), CA Piraeus, 603/1988. China: Nanjing Automobile Co. v. Singapore Peace Shipping Co., [Nanjing] as reported by Chen, supra note 10 at 95-96.

${ }^{45}$ France: The Armorique, supra note 43 at 227. In France the defence does not frequently succeed before the courts. Scapel, supra note 43 at 734-735. Italy: Pretore di Genova, 22 September 1970 (1970) Dir. Mar. 541 at 543 [Pretore] stating that 'any' adverse weather compromising the maritime venture may constitute a sea peril, Trib Trieste, 9 Oct. 1972, (1973) Dir. Mar. 70 at 77 [Trieste 1972]. Righetti, supra note 9 at 744 (note 134) referring to English doctrine and case law. Greece: as reported by Pampouki, supra note 14 at 178 also referring to case law. Even though Chinese law appears to view the extraordinary character of sea perils like English law does (sea perils do not need to be extraordinary in nature) it is rather unlikely that winds of force 7-8 constitute a sea peril in China. Interview of the author with Yao Hongxiu, Professor of Maritime Law, Law school, SMU (Shanghai Maritime University) in China regarding the force of the wind and sea perils.

${ }^{46}$ Ibid. For China see Ningbo Weike JingHua Import and Export Ltd. v Haishuo International Shipping (Shanghai) Ltd. et al. (29 November 2008), Ningbo Maritime Court Commercial Trial Decision 220, available at: Law Library http://www.law-lib.com/cpws/cpws_view.asp?id=200401294258; Shanxi Gufengji (Conglomerate) Ltd. v French Dafei Shipping Ltd. (27 July 2005), Tianjin Maritime Court Commercial Trial Decision 53, available at: Bai Du Wen Ku http://wenku.baidu.com/view/33cfc4e5524de518964b7d18. html.

${ }^{47}$ Supra notes 8, 9, 13 and accompanying text. It is only under Greek domestic law that the sea peril exception appears as an independent exoneration clause.
} 
to the civil law force majeure concept ${ }^{48}$. The latter is described as a natural or manmade occurrence which is unforeseeable and irresistible, rendering performance of a contractual or an extracontractual obligation impossible ${ }^{49}$. The standard of care that a carrier needs to prove to justify the presence of a force majeure event varies from country to country: France and China require a reasonably unforeseeable and irresistible occurrence ${ }^{50}$ whereas Greece mostly refers to unavoidable events by utmost diligence and care (higher standard of care than reasonableness) ${ }^{51}$. Italian law is not clear on whether reasonableness or a higher standard should apply to the unavoidability of the event ${ }^{52}$. The civil law defence is strictly interpreted in practice: Only extreme weather conditions (such as a hurricane, a cyclone or their effects) may exonerate the carrier $^{53}$.

Apart from the traditional case law trend approximating sea perils to force majeure events, there are cases that dissociate the exception from the domestic force majeure concept. These do not insist on the unforeseeability or the irresistibility of a sea peril but

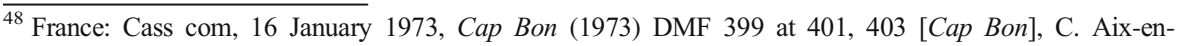
Provence, 19 June 2008, (2009) BTL 579-580, Jurisclasseur, «Force Majeure au Regard du Péril de Mer» (September 25 2002) Fasc. 465-20(QL)[hereinafter Jurisclasseur]. Italy: Cass, 4 April 1957 (1958) Dir. Mar. 67 at 70 No. 1150, CA Messina, 25 January 1980, (1980) Dir. Mar. 632 at 639. Doctrinal references: Trieste 1972, supra note 45 at $71 \mathrm{~s} \mathrm{(note} \mathrm{Giorgio} \mathrm{G.} \mathrm{Dorfles),} \mathrm{Righetti} \mathrm{supra} \mathrm{note} 9$ at 741-742. Greece: this is also the case of the Greek sea peril liability exception: CA Piraeus, 603/1988 (61220), Pampouki, supra note 14 at 179 and 539. China: Ping An Property Insurance Company of China Ltd. Beijing Branch v. Compania Chilena de Navegacion Interoceanica S.A. (18 October 2010), Shanghai Maritime Court Commercial Trial Decision 948, available at: Fa Sou http://www.fsou.com/html/text/fnl/1183110/118311095.html; Nanjing West X Hardware Industrial Co v. Shanghai Xin X Logistics Co et al. (14 December 2009), Guangzhou Maritime Court Trial Decision 218, available at: Law Library http://www.law-lib.com/cpws/cpws_view.asp?id= 200401858018 [Guangzou]. Interview of the author with Yao Hongxiu, Professor of Maritime Law, Law school, SMU (Shanghai Maritime University) in China.

${ }^{49}$ On the civil law defence, see France: François Terré, Philippe Simler, Yves Lequette, Droit civil—Les Obligations, 10th ed. (France: Dalloz, 2009) at 585-588 [Terré], Italy: Francesco Galgano, Trattato di Diritto Civile, Tome II (Italy: CEDAM, 2009) at 53-55 [Galgano]. Greece: Mix. P. Stathopoulos, Гعvıкó Evoхıкó $\Delta i$ k $\alpha$ เo (Athens, Greece: Sakkoula editions, 2004) at 307-311 [Stathopoulos]. China: Yuanshi Bu, Chinese Civil Law (Germany: Verlag, 2013) at 70-71 [Yuanshi Bu], Junwei Fu, Modern European and Chinese Contract Law: A Comparative Study of Party Autonomy (Kluwer Law International, 2011) at 133.

${ }^{50}$ France: Terré ibid at 587 and Cap Bon, supra note 48 at 400-401 (sea perils/force majeure). China: Yuanshi $\mathrm{Bu}$, ibid. Lester Ross, 'Force Majeure and Related Doctrines of Excuse in Contract Law of the People's Republic of China' (1991) 5J. Chinese L. 58 at 68 stating that the civil law defence closely follows the French or continental choice of language. The vagueness of the terms used in Chinese law to define the civil law defence leaves judges a large margin of appreciation in deciding if a debtor is liable or not. Daniel Rubenstein, 'Legal and Institutional Uncertainties in the Domestic Contract Law of the People's Republic of China' (1997) 42 McGill L.J. 495 at 521.

${ }^{51}$ Greece favours the subjective theory of force majeure regarding sea perils. As reported by Stathopoulos supra note 49 at 310-311 (force majeure in general) and Pampouki, supra note 14 at 540 (force majeure-sea perils).

${ }_{52}$ Case law and doctrine adopting a higher standard of care than ordinary diligence (reasonable care) in avoiding the supervening event: Cass, 6 February, 1985, n. 864, Cass, 14 May 2014, n. 23532, Galgano supra note 49 at 55 (force majeure in general) and Trieste 1982, supra note 44 at 543 (sea perils-force majeure). Case law and doctrine adopting a reasonableness standard with regards to the irresistibility of the force majeure event: Massimiliano di Piro, Responsabilita Civile (Italy: Simone, 2007) at 148 (force majeure in general), CA Trieste, 29 April 1957, (1957) Dir. Mar. 200 at 202, CA Messina, supra note 48 at 639 (sea perils-force majeure).

${ }^{53}$ France: CA Paris, 27 June 2013, (2013) 3473 BTL 543 at 543-544. Italy: CA Messina, supra note 48 at 639. China: Henry R. Zheng, China's Civil and Commercial Law (Asia: Butterworth, 1988) at 38.
} 
rather on the abnormality of the occurrence and the absence of negligence on the part of the carrier or his agents - usually based on a breach of article III obligations ${ }^{54}$. This trend is favoured by Italian law, while in France, it constitutes one of the judicial views present, and in Greece, some recent cases sanction it ${ }^{55}$. In China, cases that detach the sea peril defence from the characteristics of the force majeure concept described earlier have not been identified. However, the above-mentioned unforeseeability of a sea peril is deemed, overall, to be a flexible requirement ${ }^{56}$. When the sea perils' unforeseeability is not stressed upon, the exercise of reasonable care on the part of the carrier to guard against the event, the damage to the vessel, the size of the vessel, the location and duration of the adverse weather are some of the circumstances taken into in order to establish the defence ${ }^{57}$. In all cases, if the carrier or his agents are negligent in properly stowing, securing or caring for the cargo and this causes the damage or loss of the goods, then article 51.1.3 of the Chinese Maritime Code will not exonerate him ${ }^{58}$.

The following cases in France, Italy and Greece attest to the recent case law trend detaching the sea peril exception from the force majeure concept: In the French SaintLouis case ${ }^{59}$, the merchandise on board the vessel arrived damaged at destination following rough weather encountered along the voyage in the Mediterranean Sea (winds of force 6-9, rough seas and a gust of wind of force 10). In the action that followed, the carrier invoked in vain the sea peril exception. In stating that the Hague Rules do not require a sea peril to be unforeseeable and irresistible, the court of appeal noted that the mentioned weather conditions were not abnormally harsh or causing unusual difficulties for the time of the year the voyage took place, especially for a carrier who had often followed the same itinerary. It was the carrier that should have taken more appropriate measures - such as strengthening the lashing of the merchandise-against the weather conditions ${ }^{60}$. He could not, therefore, escape liability. In the

\footnotetext{
${ }^{54}$ France: Cass com, 1 December 1992, (1993) DMF 45, No. 90-20083 available at: www.legifrance.gouv.fr [The Houtmangracht], The Armorique, supra note 43 at 227, 231, CA Rouen, 30 June 1972, (1972) DMF 722 at 725 confirmed on appeal: Cass com, 2 April 1974, no. 72-14430 available at: www.legifrance.gouv.fr [Ville d'Anvers], CA Aix-en-Provence, 23 February 1993, (1994) DMF 370 at 372 [Saint-Louis] and Jurisclasseur, supra note 48. Italy: Cass, 21 June 1974, (1975) Dir. Mar. 348 at 351, 352 [Cass 1974], Trieste 1972, supra note 45 at 77, Pretore supra note 45 at 543. For doctrinal references to this judicial trend see: Trieste 1972, supra note 45 at $71 \mathrm{~s}$ (note Giorgio G. Dorfles), and Sergio M. Carbone, Contratto di Trasporto Marittimo di Cose $2^{\text {nd }}$ ed (Milano: Giuffré Editore, 2010) at 351, 352 [Carbone]. Greece: CA Piraeus, 259/1990 (3375), CA Piraeus, 289/2005 (382874), CA Piraeus, 373/1997 (182353). See also Pampouki, supra note 14 at 540-541 and 179-180 for this doctrinal/judicial view.

${ }^{55}$ Italy: Tullio, supra note 9 at 676, Carbone ibid. France: Jurisclasseur, ibid. Greece: as reported by Pampouki, ibid.

${ }^{56}$ Doctrine states that academics in China accept the trends present internationally, one of them emphasising the sea perils unforeseeability while the other does not. The latter view insists more on the facts of the case and various considerations to take into account which are explained as follows. Yuzhuo Si, Maritime Law Monograph, 2nd ed (in Chinese) (Beijing, China: China Renmin University Press, 2010) at 90, 91 [Yuzhuo]. Pr. Yuzhuo $\mathrm{Si}$ is one of the drafters of the Chinese Maritime Code, and his opinions are deemed authoritative in China. See also 'XianRen' Ship Cargo Damage Dispute' (26 May 2002), available at: China Foreign-related Commercial And Maritime Trial http:/www.ccmt.org.cn/shownews.php?id=999 stating, in fine, that the sea peril (Hague Rules) unforeseeability is a flexible one. Interview of the author with Yao Hongxiu, Professor of Maritime Law, Law school, Shanghai Maritime University (SMU) in China.

57 Yuzhuo, ibid.

${ }^{58}$ Guangzhou supra note 48, Smart Freight supra note 43, Nanjing, supra note 44 and John Mo, supra note 11 at 98 .

59 Saint-Louis, supra note 54.

${ }^{60} \mathrm{Ibid}$ at 373.
} 
Ville d'Anvers ${ }^{61}$, a cargo of flour was damaged in transit when rough seas and winds vacillating from force 3 to force 10 were encountered at sea. The adverse weather caused the vessel to heave aback and navigate at different speeds while following various routes. The court of appeal exonerated the carrier stating that sea perils do not need to present the characteristics of force majeure and are evaluated less strictly under the Hague Rules than under domestic law. The weather conditions in this case, their effect on the vessel (navigation at different speeds while following various routes, deterioration of parts of the vessel) and the absence of negligence on the part of the carrier or his agents justified the presence of a sea peril.

In the Italian 1974 Supreme Court case ${ }^{62}$, winds of force 7 and rough seas prevailing en route caused damage to the transported goods. In the action that followed, the carrier invoked the sea peril exception with no success. In distinguishing the defence from the force majeure concept, the court stated that the prevailing weather conditions did not cause serious damage to the vessel and the carrier could have guarded against the event by exercising ordinary diligence in better stowing the cargo ${ }^{63}$. Previously, a court of Trieste decision ${ }^{64}$ followed a similar reasoning in upholding the sea peril exception. Here, the adverse weather conditions in transit (winds reaching force 9-10 and rough seas) caused the vessel to pitch and roll violently, creating shocks and vibrations to the rotating propellers. These circumstances created extraordinary difficulty in navigating the vessel, and the cargo transported was displaced and damaged. In exonerating the carrier, the court noted that this liability exception should not be assimilated to the domestic force majeure concept but should include, instead, events that the carrier could avoid by the exercise of ordinary diligence considering the type of vessel involved, the type of navigation it is destined to, the location and time of the year the voyage takes place and the nature of the transported goods ${ }^{65}$.

Finally, recent Greek cases also dissociate the sea peril defence from the force majeure concept. In the 1990 court of appeal of Piraeus case ${ }^{66}$, a cargo of milk travelling from France to Piraeus was damaged when the vessel carrying it encountered rough seas and strong winds of force $8-12$ in transit. These conditions obliged the captain to anchor the ship for several days. After its departure, the vessel again encountered winds of force 8-10 and was struggling against the waves. In the action that followed, the carrier successfully invoked the sea peril exception. The court found that the event constituted a sea peril because of its unusual intensity, its effect on the maritime venture and because the captain had exercised reasonable care in adequately securing and attaching the cargo. It distinguished sea perils from force majeure stating that the former does not need to be unforeseeable and does not require the carrier to act with utmost diligence and care. In a more recent case of the court of appeal of Piraeus ${ }^{67}$, the court followed the reasoning of its 1990 holding. In this case, however, the adverse

\footnotetext{
${ }^{61}$ Ville d'Anvers, supra note 54.

${ }^{62}$ Cass 1974, supra note 54.

${ }^{63} \mathrm{Ibid}$ at 352. Carbone, supra note 54 at 350-352 on the event's unavoidability. The author suggests that the latter also refers to the event's unforeseeability. In practice, however, Italian case law does not comment often on the unforeseeability of the supervening occurrence.

64 Trieste 1972 supra note 45.

65 Ibid at 77.

${ }^{66}$ CA Piraeus, 259/1990 (3375).

${ }^{67}$ CA Piraeus, 289/2005 (382874).
} 
weather conditions (winds of force 6-8 in the North Adriatic Sea and rough seas) and the resulting cargo damage did not provide an adequate ground for the carrier's exoneration. In dissociating this carrier exception from the domestic force majeure concept, the court held that the prevailing weather conditions were not abnormal for the region and the time of year they occurred. Further, there was negligence of the carrier in loading, stowing and securing the cargo on board the vessel ${ }^{68}$. Thus, the sea peril liability exception could not be applied.

\section{Findings and analysis: identifying common ground}

This part of the study will compare and analyse the principles described earlier. As stated, the Hague-Visby rules do not provide clear guidance as to the treatment of the sea peril exception, leaving the task of defining its elements to the courts. Scholars and the courts have not provided an all-embracing definition of the defence but comment on its characteristics and stress the need to uniformly interpret it. Keeping this in mind, similarities in the judicial treatment of sea perils will be adopted since they promote uniformity. Differences in the treatment of the exception will be further discussed.

The general characteristics of the sea peril exception are shared by all the jurisdictions herein examined and will, therefore, be adopted in delineating a uniformity proposal. In all the countries concerned, sea perils constitute events specific to sea navigation and peculiar to the sea or the ship at sea, such as storms, tides, collisions and incursion of seawater. Their presence is determined on a case-by-case basis taking into account highly diversified but relevant factors: the type of occurrence, the condition of winds and sea, their duration, their location and the time of year they take place, their effect on the vessel and the goods, etc. Although in all the jurisdictions it is common ground to treat sea perils as extraordinary events, in reality, the defence may apply to occurrences that are not extraordinary in nature (collision/sinking in calm waters, weather conditions of no exceptional intensity) ${ }^{69}$. Seeking to avoid confusion as to the scope and the nature of incidents that may justify the presence of this exemption, the author agrees with Scrutton that it would be preferable to replace references to 'extraordinary' sea perils by 'out of the ordinary course of the adventure' ${ }^{70}$ occurrences. The latter does not specifically target the intensity or exceptional nature of the prevailing conditions in describing a sea peril and better reflects, therefore, the legal status quo.

A striking difference in the laws of the countries under examination lies in the use of the force majeure defence in the place of the sea peril exception in civil law countries ${ }^{71}$ and the absence of this judicial trend in common law. The difference in perception does not promote a uniform treatment of the exception. The drafters of the Hague-Visby

\footnotetext{
68 Ibid.

${ }^{69}$ Supra notes 27, 28, 36, 37, 45 and accompanying text. This remark is made with some reservations regarding Chinese law and the intensity of weather conditions. Supra note 45.

${ }^{70}$ Following the suggestion of Scrutton, supra note 16 at 208.

${ }^{71}$ Supra notes 48-53 and accompanying text. The use of the force majeure concept in the place of sea perils is based on a legal or judicial treatment of the exception in the civil law countries under examination. See, for example, the English version of the Chinese Maritime Code (MCPRC) article 51 that refers to 'force majeure and perils, dangers and accidents of the sea or other navigable waters' in order to exonerate the carrier, while the Chinese version of the article uses the term 天灾 (tian zai) meaning 'act of God'. Supra notes 11-13 and accompanying text.
} 
Rules were conscious of the different views present. They knew that a number of the excepted perils proposed - including the one under examination-corresponded to the French and other civil law countries' force majeure concepts. However, they refused to refer to force majeure in the rules, stating that common law and civil law views of carrier liability differ and that the carrier's excepted perils had to be phrased in a way that could be understood in common law and civil law alike ${ }^{72}$. In other words, the drafters chose to distance themselves from domestic law terms - such as force majeure - favouring in this way the objective of uniformity pursued by the rules.

The use of the force majeure concept to describe sea perils does not further advance uniformity if one considers that the civil law defence is variably defined in different civil law countries. As above-mentioned, Greek law favours the subjective theory of force majeure with respect to sea perils referring to unavoidable events by measures of utmost diligence and care, while the corresponding French and Chinese concepts do not adopt such a high standard of care, and Italian law is not clear on this point ${ }^{73}$. In light of these considerations, the domestic force majeure concept cannot form the basis of a uniform treatment of the sea peril exception. It does not have an exact counterpart in common law and is subject to parochial interpretations at the domestic level. It will, therefore, not be used it in the present proposal.

Another difference in the treatment of sea perils revolves around their (un)foreseeability. In most jurisdictions herein examined, there is increasing support for the position that this element is not a (strict) condition of application of the exception. This is the case of Australian, English, Italian and recent French and Greek decisions, as well as Chinese law. Following this view, foreseeable sea perils may exonerate the carrier. However, Canadian cases, some English decisions and part of French, Chinese and Greek case law insist that sea perils should constitute unforeseeable occurrences. Various trends are, therefore, present in international case law regarding the sea peril (un)foreseeability.

Tetley shares the Canadian case law position and criticizes the Australian Bunga Seroja on this point. He states that allowing foreseeable sea perils to exonerate ocean carriers encourages ship owners and charterers to venture forth into anticipated stormy weather or press on into a storm once encountered, secure in the knowledge that they will escape liability for storm-related damage to cargo ${ }^{74}$. Carver, on the other hand, notes that even abnormal weather conditions can be foreseen today ${ }^{75}$. How pragmatic is it, therefore, to cling to the sea perils' unforeseeability as a requirement for its application?

Looking at the Hague-Visby Rules, it is obvious that the sea perils' (un)foreseeability is not mentioned. In the draft article 4 proposed in 1923, the sea peril exception was phrased as it appears today in the Hague-Visby Rules: 'perils, dangers and accidents of the sea or other navigable waters ${ }^{76}$. This phrasing was finally agreed upon ${ }^{77}$ with no further mention made.

\footnotetext{
${ }_{72}$ Travaux, supra note 15 at $376-377$.

${ }^{73}$ Supra notes 50-53 and accompanying text.

74 Tetley, supra note 36 at 1045.

${ }^{75}$ Carver on Bills of Lading 3rd ed. (London: Sweet \& Maxwell, 2011) at 709 [Carver]. Carver supports the Bunga Seroja holding. Other authors state that under English law, the unforseeability of a sea peril is merely a 'point of view' and not a 'decisive factor' in determining its presence. M.L. Hendriske, N.H. Margetson, N.J. Margetson, Aspects of Maritime Law (Netherlands: Kluwer Law International, 2008) at 172.

76 Travaux, supra note 15 at 369-370.

${ }^{77}$ Ibid at $404-405$.
} 
Considering the absence of an unforeseeability criterion in the Hague-Visby Rules, sea peril defence and the presence of an increasing judicial trend to exonerate carriers for foreseeable sea perils, the author agrees with Carver's view that the unforeseeability element of a sea peril should not be emphasized. An important consideration in this regard is that, nowadays, few occurrences at sea are unforeseeable. For example, adverse weather conditions - winds of force 8-12 and large waves in the Atlantic Ocean during winter - are predictable. If the carrier is always regarded as wrong in navigating or continuing to navigate his vessel in the presence of foreseeable adverse weather, then the sea peril exception risks becoming obsolete since few occurrences are unforeseeable at sea today. This may, in turn, indirectly affect commercial activity involving carriage of goods by sea. In effect, if the carrier refrains from navigating his vessel due to fear that he may be liable in the presence of foreseeable (weather) conditions, commercial activity involving carriage of goods risks slowing down. In Bunga Seroja, the court rightfully noted: ${ }^{78}$

If every ship of the size, structure and functions of Bunga Seroja were obliged to remain in, or return to, harbour upon receipt of weather forecasts predicting gales in the Great Australian Bight or like stretches of ocean, serious inefficiencies would be introduced into the carriage of goods. The consequent costs of ships standing by would be wholly disproportionate to the marginal utility of such precautions.

From different points of view, therefore, exonerating the ocean carrier in the presence of foreseeable sea perils is a more pragmatic solution than insisting on it being an unforeseeable occurrence.

The author understands, in this regard, the position of Tetley who, in disagreeing with Bunga Seroja, argues that such a holding encourages carriers to venture in foreseeable adverse weather conditions secure in the knowledge that they will escape liability. However, avoiding abuse on the part of carriers and safeguarding cargo interests does not necessarily imply that unforeseeability needs to be a condition of application of the sea peril exception. It is suggested, instead, that the carrier's exoneration as well as the safeguarding of cargo interests lies in a stringent examination of the carrier's or his agents' absence of negligence regarding a sea peril ${ }^{79}$.

Following the author's proposal, a vessel should be able to (continue to) sail in anticipated adverse weather conditions and the carrier should be exempted from liability if his decision to commence or continue the voyage is reasonable considering all relevant circumstances (size of the vessel, intensity, duration, location of the weather conditions, type of cargo transported, etc.) and provided that he takes reasonable measures to confront sea perils (for example, by well securing the cargo, reducing the vessel's speed, etc.). If, however, a reasonable carrier would not have commenced or continued the voyage in the presence of foreseeable adverse weather conditions or if the carrier fails to take reasonable measures to confront the foreseeable weather, negligence may exist and consequently the exemption should not operate ${ }^{80}$. In this regard, the carrier's or his agents' negligence can be viewed as a far-reaching concept referring not only to the absence of reasonable measures taken in tackling the event

\footnotetext{
78 Bunga Seroja, supra note 16 at para 149.

${ }^{79}$ As Carver notes, the emphasis in determining the presence of a sea peril should really be put on the phrase 'guarded against' rather than on the word 'foreseen'. Carver, supra note 75 at 709-710.

${ }^{80}$ The same reasoning should apply for other sea perils such as accidental incursions of water.
} 
after it occurs but also to the absence of such measures present in preparing for the voyage or during the voyage (for example, improper stowage, protection of the cargo, etc.). This is the meaning attributed to the concept following case law in the mentioned jurisdictions ${ }^{81}$. Under these circumstances, the carrier's absence of negligence constitutes the key element in seeking the carrier's exoneration whereas the unforeseeability of the event is not a determining factor in establishing the presence of a sea peril.

Focusing on the carrier's absence of negligence rather than on the unforeseeability of a sea peril is not a proposal made in a vacuum. As stated, in all jurisdictions in question, the negligence of the carrier, for example, in not better securing, stowing or caring for the cargo renders the carrier liable ${ }^{82}$. This is particularly so under English law which inspired the list of exceptions contained in the Hague-Visby Rules ${ }^{83}$. The situation contrasts the sea perils' unforeseeability element whose importance divides international case law. Since common elements in the judicial treatment of the exception are retained by the author's uniformity proposal, the absence of negligence requirement cannot be omitted.

Allowing for foreseeable events to constitute sea perils is a carrier protective proposal and may lead to the frequent exoneration of carriers disadvantaging cargo interests as Tetley seems to suggest. This may, in turn, disadvantage cargo countries like Canada that favour shippers' interests in insisting on the sea perils' unforeseeability as a condition of application of the defence ${ }^{84}$. In trying to counterbalance this advantage attributed to carriers and with a view to attaining a uniform but just solution, it is suggested that courts rigorously apply the carrier's or his agents' absence of negligence. Today, modern vessels are able to withstand rough weather and storms ${ }^{85}$. As a result, the fact that cargo is damaged or lost in the presence of a foreseeable peril may very well suggest that the carrier or his agents have not exercised reasonable care in carrying or keeping the cargo or in providing a seaworthy vessel. In such cases, courts should consistently and rigorously examine the carrier's negligence based on all the relevant circumstances and not easily allow the defence to operate on this ground. Any negligence on the part of the carrier or his agents which is identified as a cause of the loss or damage to the cargo should disallow the operation of the defence. Although such considerations are taken into account by existing case law in the mentioned jurisdictions, the novelty of the proposal resides in the emphasis put on a scrupulous monitoring of the carrier's or his agents' negligence rather than on the sea peril's unforeseeability. The former is protective of cargo interests and aligns with the sea perils being an exception to the principle of carrier's liability.

\footnotetext{
${ }^{81}$ Supra notes 20, 58, 60, 63, 68 and accompanying text and supra notes 29, 41. See also Bunga Seroja, supra note 16 at para 226. The author of the present study disagrees, on this point, with the burden of proof forwarded by the Australian Bunga Seroja following which in the absence of carrier's negligence the sea peril exception should not be examined (supra note 25 and accompanying text). Rather, it is suggested that the carrier's negligence or absence thereof be examined jointly with the sea peril exception as was the case in Gamlen. Burden of proof rules are not commented on in detail in the present article.

The carrier's negligence does not only refer to his obligations vis-à-vis the cargo but may also include the vessel's unseaworthiness. The latter does not make the object of the present study.

82 Ibid.

${ }^{83}$ Supra note 29 and accompanying text. Travaux, supra note 15 at 389-390 commenting on Hague and Hague-Visby article 4.2 following the proposal of the English delegation.

${ }^{84}$ However, Australia, also a cargo country as mentioned in Bunga Seroja (supra note 16 at para 180), may exonerate the carrier in the presence of a foreseeable peril as this case declares.

${ }^{85}$ Scapel, supra note 43 at 734-735.
} 
The last difference in the treatment of the sea peril exception cannot go unmentioned. It refers to the tendency present in most civil law countries under examination (France, Italy and China) to group together different Hague-Visby Rules exoneration clauses - including the present one-contrary to their common law counterparts ${ }^{86}$. The grouped exceptions may constitute force majeure events although this trend is not always the only one present. The tendency to group together Hague-Visby Rules exoneration clauses reflects the civil law style of codification of rules ${ }^{87}$. In effect, one of the main characteristics of civil law is the structuring of legal rules under general categories and their phrasing in an abstract manner. This characteristic contrasts the common law approach which avoids establishing extremely general principles or wellstructured, predetermined legal categories. Common law jurists prefer reasoning on a case-by-case basis following specific factual situations. Thus, they are more at ease with the long list of carrier exoneration clauses contained in the Hague-Visby Rules ${ }^{88}$. Under these rules, the sea perils' defence is a separate exoneration clause from all the others. It presents its own characteristics that distinguish it from the rest of the exceptions. For example, unlike acts of God which are natural causes of damage or loss that may or may not be specific to the sea element, sea perils are natural or manmade events peculiar to the sea or to sea navigation ${ }^{89}$. These subtle but important differences between the two exceptions tend to matter less when they are grouped together and/or are treated as force majeure events. Domestic courts may then be tempted to comment on the characteristics of the group exception or the characteristics of force majeure that describes the group, rather than attribute the required attention to the specific characteristics of each exoneration clause ${ }^{90}$. In order to advance clarity in the applicable law and avoid the tendency present in civil law countries to treat sea perils as force majeure events - an assimilation that the present study has rejected - the sea peril exception constitutes an independent exoneration clause under the author's proposal. It is not treated as a force majeure event but rather as a specific to the sea, out of the ordinary course of the adventure occurrence taking place in the absence of negligence on the part of the carrier or his agents. The dissociation of the sea peril exception from other exoneration clauses does not only promote clarity regarding its treatment. It also maintains consistency with the wording of the Hague-Visby Rules. As such, it is favoured in pursuing uniformity.

\footnotetext{
${ }^{86}$ Supra notes 7-14 and accompanying text. Greek legislation has not grouped the sea peril exception with others. Common law jurisdictions maintain the 17 carrier exoneration clauses as they appear in the Hague and the Hague-Visby Rules.

${ }^{87}$ For what follows see Galgano, supra note 49 at 51-52, Sylvio Normand, 'An Introduction to Québec Civil Law' in Aline Grenon and Louise Bélanger Hardy, ed, Elements of Quebec Civil Law: A Comparison with the Common Law of Canada (Toronto: Thompson Carswell, 2008) 25 at 56-65 and Donald Poirier, 'La Common Law: Une Culture, Une Histoire et un Droit Procédural' in Aline Grenon and Louise Bélanger Hardy, ed, Éléments de Common Law Canadienne: Comparaison avec le Droit Civil Québécois (Toronto: Thompson Carswell, 2008) 25 at 35-41 and 78-86.

${ }^{88}$ See the interesting conversation of country delegates on this point in the travaux, supra note 15 at 376-377.

${ }^{89}$ For acts of God, see the English case Nugent v. Smith, (1876), 1 C.P.D. 423 (CA) which has also been cited in this context by Canadian and Australian cases. Berlingieri, 2014, supra note 44 at 33 noting that the act of God exoneration clause originates from a common law text. Its meaning must, therefore, be found in common law. For sea perils, see supra notes 16, 43 and accompanying text.

${ }^{90}$ Italy: supra note 43 . France: Cap Bon, supra note 48 commenting on sea perils on the basis of the civil law force majeure concept.
} 


\section{Conclusion}

In the absence of clear guidance provided by the text of the Hague-Visby Rules in interpreting the sea peril exception, different nations adopt different interpretations of the term, and, often, various judicial trends are observed in this area within the borders of one country. In this way, legislation and/or case law may describe sea perils as force majeure, act of god, 'events non-attributable to the carrier' or simply reproduce it as is in the Hague-Visby Rules. Depending on the country and, sometimes, the court in question, cases may require that a sea peril be foreseeable or not. Following the applicable rules in the civil law and common law nations under examination, the treatment of this excepted peril can be characterized as a perilous venture.

Navigating through the sea perils' perilous waters, the present study has identified common judicial trends that should be considered at the national level. These tend to dissociate the sea peril exception from domestic law concepts like force majeure avoiding, in this way, the danger of parochial legal interpretations which are not appropriate when dealing with international instruments. Further, all jurisdictions under examination insist on the carrier's absence of negligence as a condition of application of the exception. This element is not based on domestic law concepts and can easily apply at the international level. At the same time, it allows for judicial discretion to be exercised based on the circumstances of each case. If uniformity in the application of the exception is an objective to attain, it is suggested that the way forward lies in this direction. 